Maja Brzozowska-Brywczyńska Instytut Socjologii UAM

\title{
Dr Carrot i Potato Pete w ogrodzie zwycięstwa Brytyjska propaganda na froncie domowym w czasie II wojny światowej na przykładzie plakatów z kampanii Dig for Victory!
}

Hasło „propaganda wojenna” niemal automatycznie odsyła do - rozpatrywanych już to przez pryzmat skuteczności, już to z perspektywy ich uwikłania $w$ moralne dylematy reprezentacji (nie)prawdy - strategii, za pomocą których opracowywana zostaje, uzasadniona i podtrzymywana paradygmatyczna opozycja wrogów i bohaterów oraz uzupełniająca ją dychotomiczna para oprawców i ofiar. Biorąc pod uwagę siłę strukturalistycznej, fundamentalnej dla porządkowania przestrzeni kulturowej i społecznej w ogóle (najczęściej nieusuwalnej), różnicy między nami i obcymi (generującej dalsze, już bardziej konkretne rozróżnienia), taka polaryzacja jest jak najbardziej naturalną próbą zaprowadzenia interpretacyjnego ładu w chaotycznej wojennej rzeczywistości.

Skupienie uwagi na analizie tych, samonarzucających się, propagandowych tematów może jednak w konsekwencji doprowadzić do niedowidzenia innych potencjalnych rozumień, obszarów, narzędzi i tematów propagandowej rzeczywistości. Zwłaszcza w kontekście totalnego charakteru wojen światowych warto przyglądać się propagandzie z analogicznej perspektywy jej totalnego charakteru. Ta totalność nie powinna jednak odsyłać wyłącznie do idei wykorzystania możliwie największej liczby form i środków przekazu, do operowania mocno angażującymi emocjonalnie obrazami, ale również do swoistej kapilarności propagandy 
- to znaczy jej silnego splecenia z codziennym życiem na froncie domowym. Art est celare artem.

Mówiąc inaczej, warto spojrzeć, i takie spojrzenie proponuję w niniejszym tekście, na propagandę wojenną nie tylko z perspektywy wytaczania potężnych dział retoryki opartej na argumentach moralnych, których głównym zadaniem jest podtrzymywanie nieusuwalności i funkcjonalnego charakteru wzmiankowanego podziału na naszych i obcych, ale zajrzeć również za kulisy sceny działań wojennych, na front domowy, między grządki przydomowego ogródka, do spiżarni i na kuchenny stół.

Takie przeniesienie uwagi przynosi przynajmniej dwie korzyści: po pierwsze umożliwia rozszerzenie panteonu wojennych bohaterów i - co za tym idzie - wachlarza plakatowych zabiegów perswazyjnych, a z drugiej strony pozwala przyjrzeć się z szerszej perspektywy samej logice propagandy, akcentując jej praktyczny i instruktażowy wymiar. Mówiąc inaczej, chciałabym, wykorzystując plakaty propagandowe ilustrujące brytyjską kampanię Dig for Victory!, zaproponować wzbogacenie galerii postaci, wykorzystywanych symboli i odniesień, które są o tyle ciekawe, że niekoniecznie wprost kojarzą się z kampaniami propagandowymi okresu wojny, a dalej - pokazać logikę propagandowego zagospodarowywania rzeczywistości, nie tyle poprzez bombardowanie przestrzeni publicznej i prywatnej nawoływaniami do broni, zohydzaniem wroga i gloryfikacją narodowych bohaterów, ile poprzez przenikanie się propagandy z reklamą (w tym reklamą społeczną), ekspertyza, informacją i codziennymi praktykami. Podstawowym polem odniesień pozostaje przy tym Wielka Brytania.

\section{Od wskazującego palca lorda Kitchenera do Churchilla w meloniku}

Aby usytuować specyfikę plakatów na brytyjskim froncie domowym czasów II wojny światowej w odpowiednim kontekście, warto z grubsza chociażby naszkicować główne ramy repertuaru perswazyjnego brytyjskich kampanii propagandowych I wojny światowej.

Mówiąc najogólniej, plakaty brytyjskie tamtego okresu w przeważającej mierze opierały się na silnie sprzęgniętych z tradycją pojęciach chwalebnej walecznej przeszłości, mitologii i imperium, a ich głównym 
Dr Carrot i Potato Pete w ogrodzie zwycięstwa. Brytyjska propaganda na froncie domowym...

celem było rozbudzanie uczuć i postaw nacjonalistycznych oraz promowanie zaciągu do armii, a także zbiórka funduszy na działania zbrojne. Siłą rzeczy przekaz propagandowy operował więc toposem poświęcenia dla kraju i gloryfikacji mężczyzny-wojownika (np. hasło Britain needs you at once $\mathrm{z}$ plakatu obrazującego walkę św. Jerzego [w domyśle króla] ze smokiem), jego wielkich powinności wobec Ojczyzny-Matki, niezbędności ochrony ofiar: naszych kobiet, naszych dzieci, naszej ziemi. Siła retoryczna tych przekazów opierała się więc przede wszystkim na wywoływaniu poczucia zobowiązania (i, co za tym idzie, poczucia winy) wynikającego z honoru, a jej najwyraźniejszym chyba przykładem był plakat rekrutacyjny przedstawiający lorda Kitchenera (Alfred Leete, 1914) wskazującym palcem i srogim spojrzeniem ponaglającego Brytyjczyków do wstępowania w szeregi żołnierzy walczących za ojczyznę. Tym jednak, co w plakacie owym wydaje się szczególnie ważne w interesującym nas kontekście, jest nie tyle (powielany zresztą później na plakatach amerykańskich, rosyjskich, brazylijskich czy niemieckich) niezwykle sugestywny, ekstradiegetyczny zwrot bezpośrednio i osobiście angażujący odbiorcę (wzmocniony treścią hasła-wezwania), ile mniej lub bardziej wyraźna sugestia mówiąca, że obowiązkiem cywilów jest walka i poświęcenie dla Korony. A więc nie dla siebie, dla swojej rodziny, dla swojego kraju, ale dla króla i ku chwale imperium (na plakacie $\mathrm{z}$ lordem Kitchenerem w sposób wyraźny przypomina o tym hasło: God save the King). Poprzez takie naszkicowanie (imperialnego, rojalistycznego) perswazyjnego tła propagandowych przekazów w okresie Wielkiej Wojny, odwołania do obowiązku, wielkich poświęceń i honoru były jak najbardziej zrozumiałe, tym bardziej że - jak już wspominałam - główny wysiłek propagandowy polegał na zwerbowaniu jak największej liczby żołnierzy. Oprócz tego, o czym z uznaniem pisał w Mein Kampf Adolf Hitler, brytyjska propaganda okresu I wojny światowej w mistrzowski sposób realizowała dwie strategie propagandowe: demonizowanie wroga i manipulowanie prawdą w przekazach skierowanych do ludności cywilnej. Dzięki tym technikom reprezentacji wojennej rzeczywistości, lęk, niedostatki i bezradność społeczeństwa można było skanalizować, przekuć w nienawiść, której głównym obiektem stał się „,barbarzyński Hun (szkop)”. Narracja rozwijana na plakatach propagandowych dotyczących wroga wspierała się w znacznej mierze na historiach o jego bestialskim okrucieństwie, usprawiedliwiających jednocześnie okrucieństwo własnych wojsk (dehumanizacja 
przeciwnika jest częstym zabiegiem propagandowym przekładającym się na większą gotowość do - usprawiedliwionej nieludzką naturą adwersarza - agresji wobec niego). Najlepszym przykładem takich opowieści był ogłoszony w maju roku 1915 tak zwany Raport Bryce'a (opublikowany w 30 językach jako Report of the Committee on Alleged German Outrages), zawierający listę opisanych w najdrobniejszych detalach wszelkich możliwych potworności dokonanych przez niemieckich żołnierzy na ludności cywilnej neutralnej Belgii, zwłaszcza zaś na kobietach i dzieciach - paradygmatycznych ikonach ofiar (gwałty, okrutne morderstwa, tortury, wykorzystywanie cywilów jako żywych tarcz) ${ }^{1}$. Dowodem niezwykłej siły oddziaływania raportu był znaczny wzrost liczby mężczyzn zaciągających się do wojska; umożliwił on również wszechstronne wykorzystanie postaci wspomnianego Huna, który odegrał istotną rolę $\mathrm{w}$ propagandowym krajobrazie wojennych plakatów i w społecznej wyobraźni tamtego okresu.

Dlaczego o tym wspominam? Otóż nazbyt intensywne eksploatowanie obrazu demonicznego wroga, połączone z uprawianiem czarnej propagandy (wiele przykładów z Raportu Bryce'a nie znalazło potwierdzenia $w$ faktach, a ich celem okazało się bardziej podtrzymywanie nienawiści do nieprzyjaciela - doskonale podsycanej sensacyjnym stylem raportu - niż dokumentowanie wojennej rzeczywistości, choć oczywiście trudno zaprzeczyć, że okrucieństwa takie zdarzały się po obu stronach frontu) pozostawiło $\mathrm{w}$ społeczeństwie brytyjskim dość silny uraz wobec wszelkich prób odgórnego sterowania emocjami i dyspozycjami do działania, co niekorzystnie odbiło się na możliwościach i perswazyjnej sile propagandy prowadzonej według sprawdzonych zasad w latach trzydziestych ${ }^{2}$.

Dlatego też w trakcie II wojny światowej, aby zdobyć przychylność społeczeństwa i móc przekonać je o słuszności obowiązku podejmowania wojennych zobowiązań, aby treści propagandowe trafiły na podatny grunt frontu domowego, konieczna stała się zmiana strategii perswazyjnej komunikacji władz ze społeczeństwem, odejście od skupiania się na taktyce oczerniania wroga, od czarno-białego kreślenia obrazu wojny w kategoriach cywilnych ofiar i zbrojnych obrońców, od nacisku na bezpośrednie odniesienia do narodowych symboli, uniwersalnych wartości i patriotycznych zobowiązań, na rzecz zinterpretowania jej

${ }^{1}$ Więcej na ten temat pisze na przykład Garry S. Messinger (1992).

2 Wspomina o tym na przykład Anthony Rhodes (1983). 
również jako przestrzeni życia codziennego, w której po prostu trzeba dać sobie radę. Aby uniknąć złych skojarzeń z propagandą (postrzeganą jako taktyka okłamywania, manipulacji), przekazy perswazyjne na brytyjskim froncie domowym w czasie II wojny światowej miały opierać się na strategii przekazywania prawdy (zgodnie z zasadą no propaganda), minimalizacji emocjonalnego i sensacyjnego ładunku, skupiać na rzeczowym przedstawianiu opinii publicznej informacji z frontu (co rzecz jasna nie umniejszało problemu cenzurowania tych informacji), na pozytywnych raczej niż negatywnych hasłach i obrazach, a także - co znamienne - na wykorzystaniu lekkich form rysunkowych, satyry i humoru (doskonałym tego przykładem jest seria plakatów dotyczących całkiem realnego i uzasadnionego lęku przed szpiegami, Careless talk costs life autorstwa Cyrila Kennetha Birda tworzącego pod pseudonimem Fougasse).

Choć podstawowym celem propagandowych wysiłków nadal pozostaje kwestia poświęcenia, przestaje być ono odnoszone do abstrakcyjnego, sugerującego dysproporcję między zwykłym człowiekiem a Koroną, między nami a onymi, obrazu Imperium, skupiając się zamiast tego na pojęciu domu i akcentując wizualną rolę reprezentacji rodziny, wspólnoty, naszej Anglii. O ile więc klasycznym plakatem brytyjskim na front domowy w czasie I wojny domowej jest wspominany już wskazujący palec odzianego w mundur lorda Kitchenera, sugerujący dość jednoznaczny charakter wojennego poświęcenia, o tyle w II wojnie światowej z pewnością plakatem obrazującym zmianę stosunków na linii społeczeństwo-władze byłby spoglądający przed siebie, ale już nie prosto $\mathrm{w}$ oczy odbiorcy, Winston Churchill w meloniku nawołujący „Pójdźmy razem [ku zwycięstwu]” na tle czołgów w tumanach kurzu i nieba pełnego wojskowych samolotów (autor nieznany, 1940). Idea wspólnej walki, walki wszystkich obywateli (people's war) toczonej zarówno na froncie zbrojnym, jak i domowym, angażującej nie tylko mężczyzn, ale również kobiety, dzieci i osoby starsze, stała się generalną ramą strategii propagandowych na brytyjskim froncie domowym okresu II wojny światowej. 


\section{Dig for Victory!}

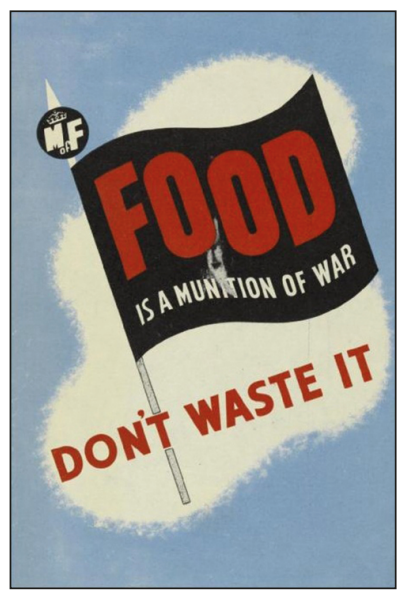

Plakat 1

Czarna flaga powiewa na błękitnym tle, a napis na niej głosi sugestywnie: „Żywność [pogrubiona czerwona czcionka, duże litery zajmujące większą część flagi] jest jak amunicja na wojnie [dopisane pod spodem małymi literami, na biało]". Poniżej [czerwony napis biegnący w poprzek plakatu, co podkreśla dynamiczny charakter przekazu] apel-rozkaz: „Nie marnuj jej!” Plakat ten (nieznanego autora), opublikowany przez Ministerstwo Żywności, odsyłał do prawdy oczywistej, łączącej dostępność bądź brak jedzenia $\mathrm{z}$ powodzeniem na wojennym froncie (plakat 1). W przypadku Wielkiej Brytanii wydźwięk zawartego na plakacie przesłania i świadomość stosowania się do jego treści miały szczególne znaczenie, gdyż - jako wyspa - była ona w znacznej mierze uzależniona od importu żywności. Statki handlowe płynące na wyspę przez Atlantyk stanowiły zaś doskonały i łatwy cel dla niemieckich torpedowców. Dostawy żywności drogą morską były więc narażone na ogromne ryzyko, co w bezpośredni sposób przekładało się na ponurą perspektywę klęski głodu, na skraju której Wielka Brytania stanęła już zresztą pod koniec I wojny światowej. Równolegle rząd brytyjski uznał, że statki handlowe przydadzą się przede wszystkim do transportu oddziałów wojskowych, broni i amunicji, a nawet samolotów na front wojenny. Efektem tych posunięć była konieczność drastycznego zmniejszenia importu żywności. $Z$ jej ewentualnymi niedoborami radzono sobie $w$ trojaki sposób. Po pierwsze, do pracy w sektorze rolnym powołano ochotniczą Women's Land Army, której zadaniem było zastąpienie brakujących męskich rąk do pracy w polu, w mleczarniach, przy wycince lasów, pomoc przy sadzeniu warzyw, w zbiorach, opiece nad zwierzętami. Po drugie - wprowadzono system racjonowania żywności, który ruszył dokładnie 8 stycznia 1940 r., dotkliwie godząc w kulinarne przyzwyczajenia Brytyjczyków (jako pierwsze objęte zostały nim bowiem kluczowe składniki tradycyjnego brytyjskiego śniadania: boczek, szynka, cukier, masło, a zaraz później jaja oraz importowana z Indii herbata; racjonowanie żywności wymusiło drastyczną zmianę nawyków żywieniowych i - co oczywiste - spotykało się z oporem 
Dr Carrot i Potato Pete w ogrodzie zwycięstwa. Brytyjska propaganda na froncie domowym...

społeczeństwa). Po trzecie wreszcie - początkowo w celu suplementacji skromnych wojennych racji żywnościowych, Ministerstwo Żywności zainicjowało w październiku roku 1939 (pod pierwotnym hasłem Grow your own food) jedną z najbardziej znanych kampanii propagandowych II wojny światowej: Dig for Victory!

W jej ramach całe społeczeństwo zostało zmobilizowane do przekształcania prywatnych ogrodów i trawników w mini-działki warzywne. Również publiczne parki, skwery i boiska, niemal każdy skrawek nieużywanego terenu (łącznie z lejami po bombach, poboczami dróg, dachami domów, parapetami), zostały przeznaczone pod uprawę warzyw. Kampania Dig for Victory! nie była jednak skierowana tylko do wytrawnych działkowiczów, ogrodników i farmerów - oprócz plakatów nawołujących do „,kopania grządek w imię zwycięstwa”, Brytyjczycy mieli „pod ręką” wszelkie użyteczne informacje wyjaśniające $\mathrm{w}$ bardzo szczegółowy sposób, krok po kroku, jak ten patriotyczny wysiłek realizować w zależności od możliwości i umiejętności. Wiedza na temat kalendarza zbiorów, samodzielnej produkcji kompostu, szkodników i chorób roślin uprawnych, przechowywania warzyw, robienia przetworów, a nawet odpowiedniej techniki wbijania łopaty w ziemię $^{3}$, była powszechnie dostępna w postaci wydawanych przez Ministerstwo Żywności broszurek. Już sam fakt ich regularnego, nieprzerwanego publikowania (niezależnie od problemów z dostępnością papieru), podobnie zreszta, jak książek kucharskich czy czasopism kobiecych, pełnych praktycznych rad dotyczących uprawiania "ogrodów zwycięstwa" oraz twórczego wykorzystania ich plonów, świadczy o wielkiej wadze kampanii. Z całą pewnościa, oprócz przyczyn pragmatycznych, przekierowanie uwagi społeczeństwa na kwestie ogrodnicze i kuchenne mogło mieć również charakter propagandy dywersyjnej. Dzięki niej pojawił się bowiem uniwersalny, bo odnoszący się bezpośrednio do wszystkich, temat zastępczy, który pozwalał utrzymać wysokie morale w społeczeństwie (posiłkując się symboliką rodziny, domu i domowego ogródka oraz gastronacjonalistycznego potencjału żywności produkowanej na brytyjskiej ziemi przez Brytyjczyków), dawał satysfakcję bycia potrzebnym każdemu jego członkowi (dzieci pomagały wyrywać chwasty w przydomowych ogródkach, kobiety robiły przetwory i tworzyły pomysłowe potrawy z ograniczonych zasobów, starsi panowie kopali ziemniaki na działce, młodzież pomagała przy zbiorach), tworzył piękny topos szacunku dla cywilnego trudu, a jednocześnie pozwalał znormalizować codzienne życie na froncie domowym. Pod koniec

\footnotetext{
${ }^{3}$ Zob. http://www.bl.uk/reshelp/bldept/socsci/visual/visres.html (dostęp: 1 X 2012).
} 
wojny hasło Dig for Victory! zostało przeredagowane tak, by mogło odsyłać nie tylko do najbliższej przyszłości (zwycięstwo w wojnie), ale pozwalało również wyobrazić sobie przyszłość dalszą powojennej obfitości, stąd też Dig for Plenty.

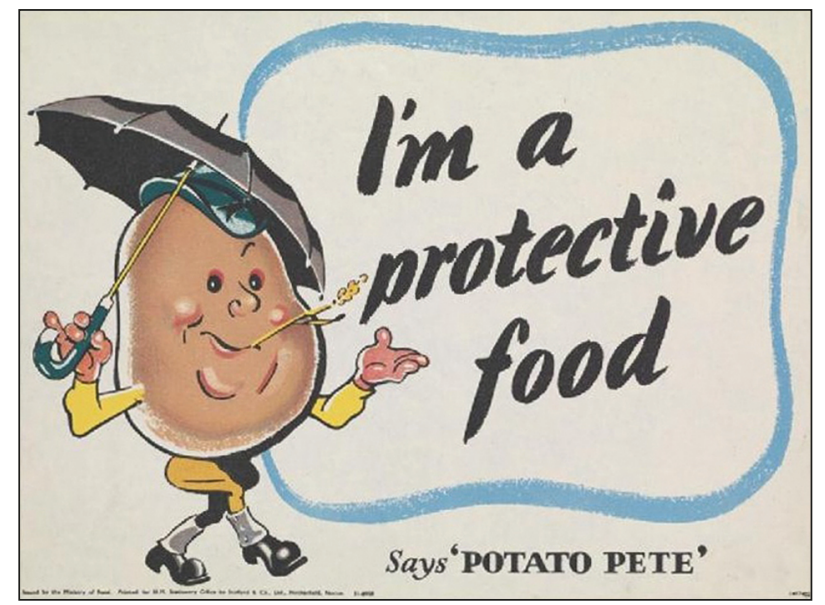

Plakat 2

W efekcie entuzjastycznego podejścia społeczeństwa brytyjskiego do realizacji idei ogrodniczej samowystarczalności, prędko pojawiły się nadwyżki najbardziej popularnych i najprostszych w hodowli warzyw: marchewek oraz ziemniaków. Aby zagospodarować ten nadmiar, Ministerstwo Żywności powołało do życia dwie postacie: Doctora Carrota i Potato Pete'a.

Potato Pete (plakat 2), uśmiechnięty ziemniak z rumianymi policzkami, w bryczesach, trzewikach na guziki, miękkim zielonym farmerskim kapeluszu na czubku głowy i z nieodłącznym kłosem w zębach skakał przez płoty i wprost do koszyka („Daję energię!”), maszerował z grabiami (zdobiąc okładki książek kucharskich), dumnie kroczył z talerzem parującej zupy w rękach („Nadaję się na dobrą zupę!”), pod parasolem („Daję ochronę!"”), a nawet prowadząc za sobą uśmiechnięty, głównie damski, tłum („Zobacz, ilu miłych przyjaciół już zdobyłem!"). Wszechobecność sympatycznej postaci uzupełniały poświęcone jej rymowanki, wierszyki i piosenki, w których zawarte były częstokroć (i częstokroć humorystyczne) wskazówki dotyczące możliwości i sposobów wykorzystania ziemniaków (np. „Zasady dobrego smaku wymagaja, abym pozostał w mundurku"). Logika ich uobecniania (podobnie zreszta, jak w przypadku marchewek) opierała się 
raczej na zasadzie dostarczania szczegółowego instruktażu, fachowej wiedzy w prosty sposób, niż na przykład epatowania obrazami głodu (zaliczenie ziemniaków do produktów "ochronnych" i dostarczających "energii" było efektem wprowadzenia podziału wszystkich produktów żywnościowych dostępnych na brytyjskim froncie domowym na trzy główne grupy: odżywczych, dostarczających energii i dających ochronę, z zaleceniem, aby z każdej z nich codziennie spożywać przynajmniej jeden produkt, co zdecydowanie ułatwiało zachowanie zdrowia i siły do walki na froncie domowym nawet w trudnych warunkach). Ten swoisty , język korzyści" był niezwykle charakterystyczny dla przekazów propagandy brytyjskiej tamtego okresu.

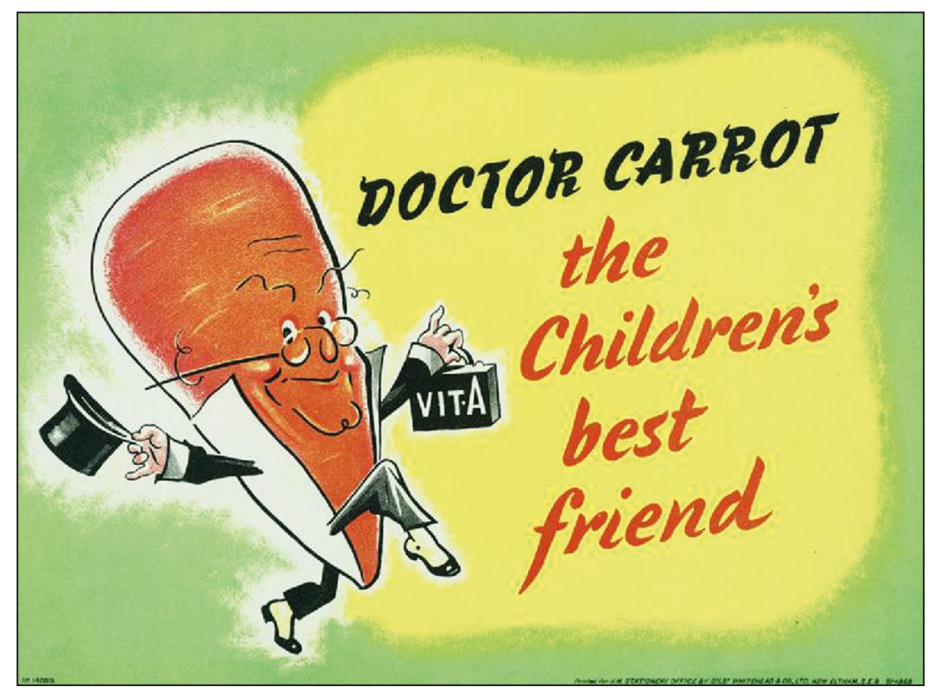

Plakat 3

W kampanii na rzecz zdrowej warzywnej diety Potato Pete'owi towarzyszył Dr Carrot (plakat 3). Dziarsko krocząc z lekarską torbą opatrzoną napisem Vit A, w białym lekarskim fartuchu, z cylindrem w dłoni i okrągłych okularkach na łysej marchewkowej głowie, spoglądał z uśmiechem na odbiorców, na nieodmiennie promiennym żółtym tle przekonując czerwonymi zgłoskami: „Dr Carrot na śniadanie”, „Dr Carrot: strażnik zdrowia”, „Dr Carrot: specjalista w dziedzinie ochrony”, „Dr Carrot: twój zimowy opiekun” czy wreszcie „Dr Carrot: najlepszy przyjaciel dzieci”. Rysunkowa, lekka formuła (w roku 1941 projekty bohaterskich marchewek zaproponował Ministerstwu Żywności także rysownik wytwórni Walta 
Disneya, Hank Porter, który stworzył postacie Carroty George'a, Pop Carrota i Clary Carrot, uzupełniające karotenowy przekaz ${ }^{4}$ ) miała zachęcić najmłodszych żołnierzy frontu domowego do zdrowego odżywiania się „w imię zwycięstwa", czyniąc to w sposób, który nie odstręczał moralizatorskim tonem i który pozwalał na łatwiejszą identyfikację z treścią zalecenia oraz z ich "głosicielami” tak podobnymi przecież do bohaterów dziecięcych bajek (treść części klasycznych angielskich rymowanek i historyjek była zresztą zmieniana tak, aby można było odnieść je do postaci Doctora Carrota i Potato Pete'a, z tym większą łatwością przekonując dzieci o konieczności zdrowego odżywiania się).

Propagandowy sukces marchewek nie ograniczał się jednak wyłącznie do popularności postaci sympatycznego warzywnego doktora. Odegrały one bowiem również istotną rolę w zwycięsko zakończonej bitwie o Anglię. Kiedy pod koniec lata roku 1940 oddziały Luftwaffe zrezygnowały z dziennych nalotów na rzecz nocnych ataków bombowych na brytyjskie miasta, odpowiedzią Royal Airforce było zainstalowanie w samolotach nowoczesnych systemów radiolokacji, co w ostatecznym rachunku dało pilotom RAF zdecydowaną taktyczną przewagę. Aby jednak informacja o prawdziwej przyczynie ich wysokiej skuteczności nie trafiła do wroga, należało zaproponować alternatywne wyjaśnienie niebywałego sukcesu nocnych operacji - uwaga opinii publicznej została zatem skupiona na argumentacji łączącej zdolność widzenia pilotów RAF w ciemnościach $\mathrm{z}$ bogatą $\mathrm{w}$ marchew dietą brytyjskiego lotnictwa. Marchewki okazały się w tym względzie o tyle poręczne, że po pierwsze wiara w ich dobroczynny wpływ na wzrok była dość powszechna w społeczeństwie (zarówno brytyjskim, jak i - co chyba szczególnie istotne - niemieckim), po drugie zaś - w świetle rozwijanych podówczas badań nad właściwościami karote$\mathrm{nu}^{5}$ - dieta marchewkowa wydawała się względnie wiarygodną przyczyną sukcesu najsłynniejszego i najskuteczniejszego z pilotów, kapitana Johna "Cats Eyes" Cunninghama (który miał zestrzelić 20 samolotów wroga ${ }^{6}$ ). Propaganda marchewkowa okazała się na tyle skuteczna, że sprawdziła się nie tylko jako narzędzie dezinformacji wroga, ale pozwoliła również przekonać sporą część Brytyjczyków do pójścia śladem swojego narodowego bohatera i zwiększenia spożycia tych warzyw. Słuszność tej decyzji podkreślał zresztą dość bezpośredni wydźwięk takich plakatów, jak ten z roku 1941: obraz miasta noca, matka z córką spiesznie przechodzą przez ulicę

4 Zob. http://www.carrotmuseum.co.uk/history4.html (dostęp: 01 X 2012).

5 Zob. http://www.carrotmuseum.co.uk/history4.html (dostęp: 01 X 2012).

${ }^{6}$ Zob.http://www.airspacemag.com/history-of-flight/Cats-Eyes.html (dostęp: 01 X 2012). 
Dr Carrot i Potato Pete w ogrodzie zwycięstwa. Brytyjska propaganda na froncie domowym...

przed majaczącą się w tle sylwetką samochodu. Dziecko ufnie przytula się do matki, ta zaś pewnie patrzy przed siebie, a w ręce trzyma wiklinowy kosz pełen marchwi. Hasło pod obrazkiem przekonuje: „Dzięki jedzeniu marchwi zachowasz zdrowie i będziesz lepiej widzieć podczas zaciemnienia" (przekaz ten był tym bardziej przekonujący, że podczas zaciemnień dochodziło do wielu wypadków drogowych i tragicznych w skutkach zderzeń ze ścianami domów, potknięć na chodnikach etc.). Tym samym, dzięki produktywności frontu domowego i pomysłowości brytyjskiego wywiadu, skromna marchew, traktowana wcześniej raczej jako pasza dla zwierząt niż jedzenie odpowiednie dla ludzi, została zrehabilitowana, zajmując ważne miejsce w krajobrazie perswazyjnych obrazów propagandowych plakatów frontu domowego.

\section{Ikoniczne plakaty kampanii: szpadel, dziecko i kosz warzyw}

Celem kampanii Dig for Victory! było zmobilizowanie Brytyjczyków do hodowli warzyw oraz zdefiniowanie dyktowanej systemem racjonowania konieczności zmiany nawyków żywieniowych jako działań na rzecz utrzymania społeczeństwa $\mathrm{w}$ zdrowiu (i w gotowości do obrony ojczyzny), jako patriotycznego obowiązku. Niezbędnym krokiem w kierunku realizacji tego założenia było prowadzenie akcji edukacyjnej, informacyjnej i propagandowej. Brytyjskie plakaty przeznaczone na front domowy stanowiły ważną część propagandowego krajobrazu wizualnego wojennej codzienności, źródło wiedzy, komentarz społeczny, kulturowy (i polityczny) do wydarzeń codziennego życia w czasie wojny, pozwalały w prosty i bezpośredni sposób szeregować i hierarchizować priorytety. Były jednak, co należy podkreślić - jedynie wycinkiem wizualnego pola propagandowego na brytyjskim froncie domowym, stanowiły tylko część całej sieci przekazów perswazyjnych i informacyjnych w formie ulotek i broszurek, kalendarzy upraw i zbiorów, książek kucharskich, audycji radiowych (stacja BBC codziennie rano nadawała krótką pięciominutową audycję o znamiennym tytule The Kitchen Front, będącą omówieniem aktualnej sytuacji żywieniowej i zestawem porad kulinarnych), kronik filmowych (tak zwane Food Flashes, emitowane przed seansami, stanowiły rozwinięcie haseł widniejących na plakatach i również zachęcały do zakładania „ogrodów zwycięstwa" argumentując między innymi, że stanie w kolejce po warzywa (które nie były przecież racjonowane) to strata cennego czasu, który 
można spędzić w produktywny sposób samodzielnie je uprawiając ${ }^{7}$, a także dziecięcych rymowanek i piosenek. Redundancja informacji miała oczywiście na celu zagwarantowanie skuteczności upowszechniania się apelu o samowystarczalność „kulinarną”, przekonanie ludności cywilnej o jej znaczeniu dla dalszych losów wojny, a także mocne ukorzenienie działań patriotycznych w rzeczywistości życia codziennego. Tym, co łączyło wszystkie te różnorodne formy przekazu i (jak się miało okazać tylko pozornie) rozproszone działania obywateli, stanowiąc kluczowy komponent przekazów propagandowych skierowanych na front domowy, było jedno słowo: zwycięstwo. W imię zwycięstwa miano bowiem nie tylko kopać grządki, ale również zdrowo jeść, szyć, dziergać, gotować, oszczędzać, segregować odpady, produkować, robić zakupy czy przetwory. Ta pozytywna metanarracja pozwalała połączyć kampanię Dig for Victory! z innymi akcjami informacyjnymi i propagandowymi, na przykład skupioną na konieczności oszczędnego wykorzystywania zasobów Salvage czy poświęconą recyclingowi, naprawom i radzeniu sobie Make do and Mend, a także z rekrutacją do Women's Land Army i czynem społecznym w ramach kierowanej do mieszkańców miast akcji Lend a hand on the Land. Dzięki temu połączeniu możliwe było także zastosowanie „zwycięskiej” retoryki, która ze wszystkich, nawet niepozornych, działań na froncie domowym czyniła formy walki z wrogiem, sytuując jednocześnie każdego obywatela, niezależnie od wieku i płci, w roli żołnierza, broniącego ojczyzny w toku codziennych zmagań z wojenną rzeczywistością. Aktami patriotycznymi było więc na przykład zbieranie odpadków dla świń, hodowanych przez lokalne „Pig clubs”, cerowanie skarpet, zbieranie aluminiowych garnków dla lotnictwa, przyrządzanie Woolton pie czy segregowanie papieru, kości i gałganków. Ten ostatni obowiązek i zarazem sposób funkcjonowania wspomnianej ,zwycięskiej" retoryki przekazów propagandowych, zgrabnie ilustruje plakat (Yeates-Wilson 1940) przedstawiający trzy kobiety (trzy pokolenia) maszerujące razem pod czerwonym sztandarem zatkniętym na proporcu z metalowego karnisza, na którym wymalowane jest białymi literami hasło, będące cytatem z przemówienia Herberta Morrisona (ministra ds. zaopatrzenia w gabinecie wojennym Winstona Churchila): „Gospodynie domowe, do boju!" [Up housewives and at'em!]. I faktycznie, wszystkie trzy kobiety, choć w kuchennych fartuszkach, starannie upię-

7 Zob. http://food.iwm.org.uk/?page_id=619 (dostęp: 01 X 2012), krótki film o Dig for Victory: http://www.nationalarchives.gov.uk/theartofwar/films/dig_victory.htm (dostęp: 01 X 2012). 
Dr Carrot i Potato Pete w ogrodzie zwycięstwa. Brytyjska propaganda na froncie domowym...

tych lokach i sukienkach z bufkami, mają srogie, wojownicze miny, a każda z nich niesie to, co może przeważyć szale zwycięstwa: naręcze starych gazet, wspomniany już karnisz i kości (z kością w pysku i równie groźną miną drepcze obok mały czarny yorkshire terrier). Hasło pod rysunkiem (na czarnym tle) głosi: „Zbierajcie papier, metal i kości. Powstaną z nich samoloty, broń, czołgi, statki i amunicja".

Mówiąc jeszcze inaczej, „kobiety, dzieci i starcy”, w propagandowej retoryce lokowani zazwyczaj po stronie ofiar, zostali obsadzeni $\mathrm{w}$ roli sprawczych aktorów wojennych działań. Co więcej, oprócz ludzi, ważnymi aktorami i bohaterami kuchennej wojennej propagandy były również zwierzęta (głównie świnie i kury nawołujące na plakatach do karmienia ich kuchennymi resztkami) oraz warzywa (zwłaszcza wspomniane marchewki i ziemniaki). W miejsce podziału na herosów i ratowane ofiary, w miejsce romantycznej, heroicznej, "męskiej“ retoryki rzeczy wielkich, pojawiła się idea (którą należało uatrakcyjnić, a uatrakcyjnienie polegało właśnie na sprzęgnięciu działań codziennych z „niecodziennymi“ wyczynami na froncie) wspólnego trudu, codziennej walki. Drobiazgowość, detaliczność tematyki plakatów z kampanii Dig for Victory!, obok ich odniesień do tego, co brytyjskie, swojskie, do ogólnych celów całego tego ogrodniczo-kuchennego przedsięwzięcia, składała się na swoistą wyobraźnię wizualną w której wszystko przypomina, że nieustannie toczy się walka i nieustannie obrazuje, $\mathrm{w}$ imię czego jest ona rozgrywana.

Plakaty wspierające kampanię Dig for Victory! posługiwały się dość prostym, wręcz ilustracyjnym przekazem wizualnym oraz instruktażowymi hasłami (np. „Jeśli chcesz mieć w swoim ogrodzie warzywa przez okrągły rok, zacznij już teraz uprawiać ogród w imię zwycięstwa" jako podpis pod rysunkiem przedstawiającym kosz po brzegi wypełniony dorodnymi, świeżymi warzywami w soczystych kolorach), z rzadka jedynie oferując bardziej wyrafinowane perswazyjne formy (np. stosowanie - tak powszechnego na plakatach rosyjskich czy włoskich - montażu i retuszu bądź haseł opartych na grze słów czy montażu atrakcji). Świat przedstawiony na plakatach tworzonych i rozpowszechnianych w ramach kampanii Dig for Victory! był oczywiście wyidealizowany (staranne fryzury, śnieżnobiałe fartuszki, czyste i schludne ubrania, sielankowe obrazy, słoneczne tło), choć jednocześnie odmalowany w zdecydowanie realistycznym stylu (co czyniło go podobnym do fotografii, sugerowało raczej akt relacjonowania, wiernego przedstawiania rzeczywistości, niż jej wytwarzania). 


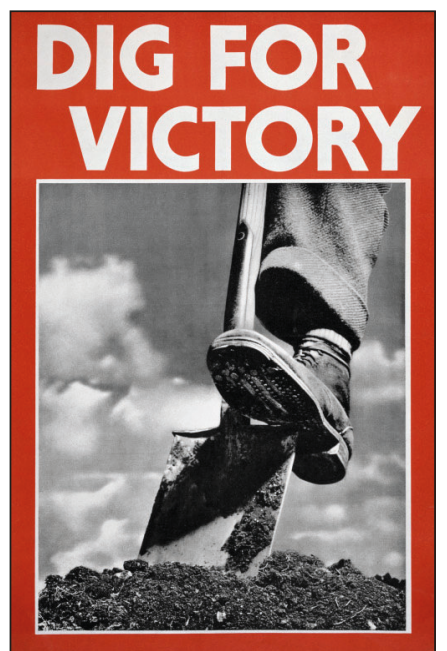

Plakat 4

Ikoniczny plakat kampanii - wykorzystywany później jako logo sygnujące kolejne materiały informacyjne i propagandowe $\mathrm{w}$ ramach Dig for Victory! - przedstawia czarno-białą fotografię obutej w cywilny, zakurzony but stopy wspartej na wbitej w ziemię łopacie, wszystko na tle słonecznego nieba (plakat 4). Zdjęcie zostało zrobione z żabiej perspektywy zarezerwowanej $\mathrm{w}$ tradycyjnej propagandowej ikonografii dla postaci bohaterów, dyktatorów, jednostek posiadających władzę. Umieszczone jest w czerwonej ramce i opatrzone nagłówkiem DIG FOR VICTORY. W innej, bardziej bezpośrednio angażującej odbiorcę, wersji tego samego motywu, w tle za stopą wspartą na łopacie zamiast nieba majaczą się dziecięce twarzyczki: zdrowe, rumiane, uśmiechnięte i pięk-

ne. Obrazowi towarzyszy wyraźniej sformułowany cel „kopania grządek w imię zwycięstwa” - „Dla ich dobra - zacznij sam hodować warzywa” (siłą napędową tego przekazu wydaje się raczej podkreślanie wagi sprawstwa, współodpowiedzialności obywatelskiej, a nie wzbudzanie litości). $\mathrm{Na}$ jeszcze innym plakacie, zdjęcie - przerobione na kolorowy rysunek uzupełnia ponaglenie (napisane wprost na rysunku czerwoną czcionką): „Teraz!" Nawołujące do podtrzymania ogrodniczego zapału hasło „Dig on for Victory!" pojawia się także na plakacie przedstawiającym uśmiechniętego mężczyznę idącego środkiem drogi przez pola, z fajką w zębach, naręczem marchwi i sałaty pod pachą, koszem pełnym warzyw w ręce i grabiami na ramieniu ( $w$ tle nieodmiennie błękitne niebo). Plakaty te $w$ bardzo zgrabny sposób pokazują specyfikę oczekiwanego przez rząd obywatelskiego poświęcenia. Stopa obuta w cywilny but, wsparta na łopacie, to symbol niewielkiej, „ludzkiej”, skali patriotycznego wysiłku, na jaki może pozwolić sobie każdy obywatel, łopata jest narzędziem jednostki, jej użycie w celu oswojenia ziemi, by wydała owoce, stanowi sprawczy, twórczy akt.

Jeszcze dobitniej przekaz ten wybrzmiewa na plakacie Dig for Victory Mary Tunbridge (data nieznana). Tyłem do widza stoi na nim małe dziecko (najprawdopodobniej chłopiec), ubrane w letni biały strój (krótkie spodenki, bluzeczka z krótkim rękawkiem, kapelusik, sandałki z białymi skarpetkami). Ziemia u jego stóp jest popękana i wyblakła od ostrego słońca padającego z góry (sugeruje to cień po dziecięcemu skrzywionych 
nóżek bohatera plakatu), natomiast ono wydaje się zmierzać w stronę znajdującej się w głębi rysunku, wywołującej niezwykle „orzeźwiający" efekt, błękitnej plamy (stanowiącej wyrazisty punkt centralny całej kompozycji) $\mathrm{w}$ jednej dłoni trzymając haczkę na długim trzonku, w drugiej ciągnącą się po ziemi łopatę (plakat 5). Plakat ten $\mathrm{w}$ zasadzie można odczytać dwojako. Z jednej strony pokazuje on, że na froncie domowym naprawdę każdy może zostać bohaterem i każdy może przyłączyć się do społecznego czynu, z drugiej jednak może (i prawdopodobnie taki miał być również jego cel) wywoływać poczucie winy $\mathrm{u}$ tych dorosłych, którzy jeszcze nie założyli "ogrodów zwycięstwa". Może wreszcie, po-

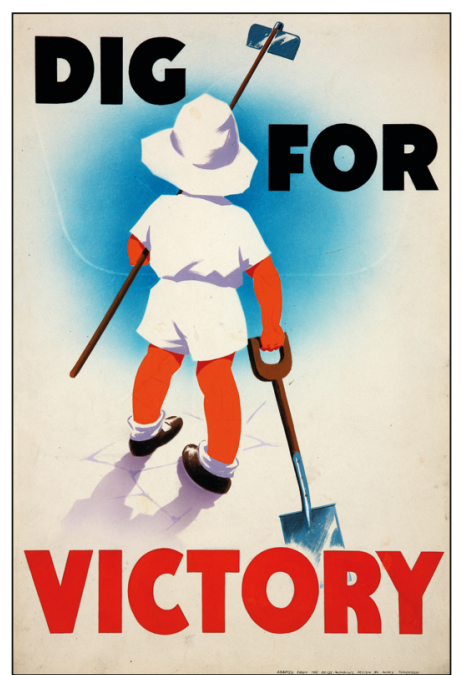

Plakat 5 przez wykorzystanie ikonicznej figury niewinności i czystości, pomóc w oddzieleniu myślenia o walce o zwycięstwo od konieczności faktycznego zabijania wrogów i przekierowaniu uwagi na inne jej konotacje, takie jak sprawstwo czy odpowiedzialność.

Pod koniec działań wojennych kampania

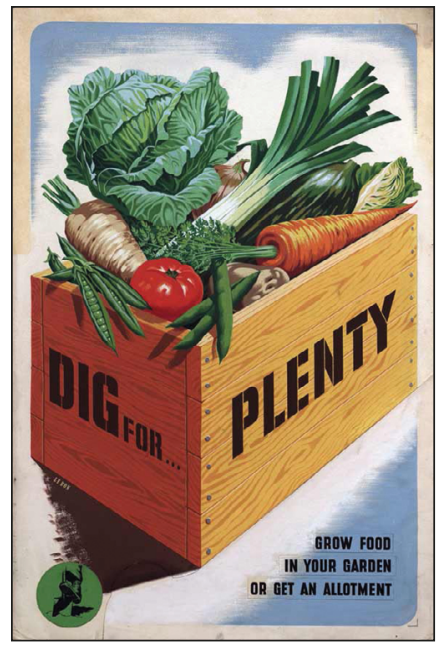

Plakat 6 Dig for Victory! zmieniła logo. Miejsce stopy wspartej na łopacie zajęła drewniana skrzynia pełna plonów i wspominane już hasło Dig for Plenty - tym samym zaś uwaga propagandy została przeniesiona $\mathrm{z}$ produkcji na konsumpcje plonów i zaangażowała głównie zarządzające frontem kuchennym kobiety, przypominając o konieczności zachowania zdrowia rodziny oraz o korzyściach płynących z jedzenia świeżych warzyw i owoców. Przejście to doskonale ilustruje plakat Mary LeBon z roku 1944 (plakat 6). Drewniana skrzynka wypełniona jest po brzegi warzywami (groszek, cukinia, cebula, pomidor, marchew, pietruszka, por, kapusta); na jednym z boków skrzynki napis: „Dig for...", na drugim większymi literami, podkreślone „PLENTY” (obfitość); rysunek skrzyni z warzywami wypełnia całą przestrzeń plakatu, błękitne tło, wokół samej skrzynki biała poświata 
uwypuklająca je z tła. Ten warzywny róg obfitości, odmalowany w głębokich, soczystych barwach sugerujących świeżość, zdrowie i dostatek miał sugerować bezpośredni związek między aktualną dietą społeczeństwa brytyjskiego a jego dobrobytem i szczęśliwością w przyszłości.

$\mathrm{O}$ ile dotychczas przywoływane plakaty mieściły się $\mathrm{w}$ ramach realistycznych, choć przerysowanych, przedstawień, stanowiąc perswazyjną

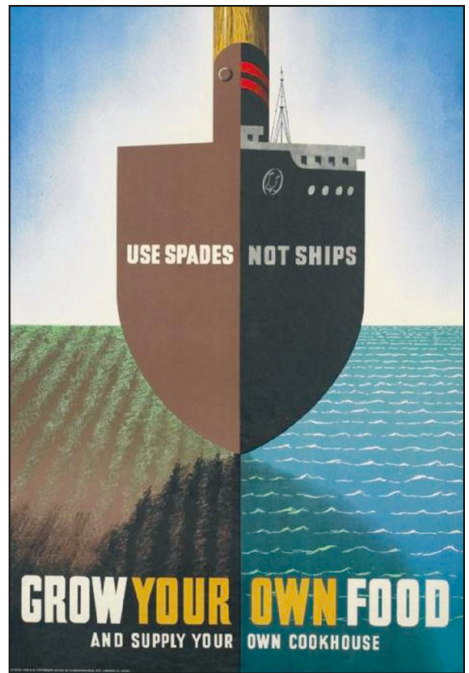

Plakat 7

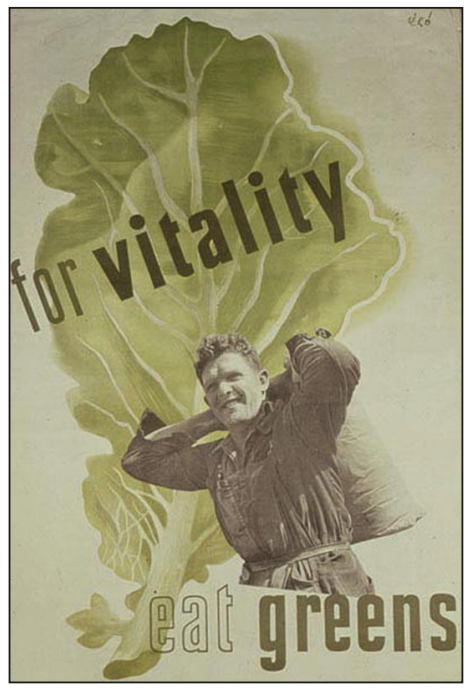

Plakat 8 ilustrację haseł nawołujących do czynienia codziennych wysiłków „w imię zwycięstwa”, można wskazać także kilka przykładów bardziej nowoczesnego podejścia do sztuki plakatu, wykorzystującej zasady montażu, wyrazistsza, bardziej sugestywną formę, wspartą na propagandowej zasadzie skracania łańcuchów skutkowo-przyczynowych, perswazyjnych zestawień obrazów przez analogię czy na zasadzie przeciwieństw. To na przykład plakat Abrahama Gamesa z roku 1942 (plakat 7) przedstawiający pół-statek pół-szpadel po części wbity w ziemię, po części zanurzony w morzu (na nieodmiennie błękitnym tle), opatrzony napisem (w wolnym przekładzie): „Polegaj na szpadlach, nie na statkach. Sam hoduj swoją żywność i sam zaopatruj swoją spiżarnię". Na podobnej zasadzie skomponowany jest też plakat Hansa Schlegera Grow your own food, również z roku 1942, przedstawiający kawałek zaoranego pola pod nieodłącznie błękitnym niebem, $\mathrm{z}$ wbitą $\mathrm{w}$ ziemię tabliczką głoszącą grow your own („hoduj sam”) i ułożonym pod spodem z warzyw (por, dwie rzepy i seler naciowy) napisem „food" (żywność), czy jego inny plakat For vitality eat greens (w wolnym przekładze: „Czerp siłę z zieleniny") (data nieznana) przedstawiający czarno-białe zdjęcie uśmiechniętego robotnika $\mathrm{z}$ workiem na plecach na tle przerośniętego liścia zielonej sałaty (plakat 8). To warzywa były głównymi bohaterami tych przekazów. 
Dr Carrot i Potato Pete w ogrodzie zwycięstwa. Brytyjska propaganda na froncie domowym...

\section{Zwyczajny obywatel prawdziwej Anglii}

Tym, co jest najbardziej interesujące, kiedy ogląda się brytyjskie plakaty publikowane w zasadzie przez całą wojnę w ramach kampanii Dig for Victory!, są idylliczne obrazki - Wielka Brytania, zielona, wiejska, słoneczna, pełna uśmiechniętych i garnących się do pracy obywateli - zestawione z wojenną wymową haseł (np. "Żywność jest jak amunicja na wojnie, nie marnuj jej!"). Dobrym przykładem tej (jak się okazuje pozornej) inkongruencji jest plakat nawołujący kobiety (bo to one głównie dowodziły na kuchennym froncie) do oszczędnego gospodarowania zasobami. Zajmujące przeważającą część plakatu hasło: „Pomóż wygrać wojnę na kuchennym froncie" (granatowa prosta czcionka na jasnym tle, apel rozbity na pięć wersów) góruje nad obrazkiem, który równie dobrze mógłby być reklamą sklepu warzywnego - oto uśmiechnięta pani domu w soczyście zielonym płaszczyku i pasującym doń toczku, z wiklinowym koszykiem na przedramieniu, dłonią w białej rękawiczce wybiera prosto ze skrzynki świeże warzywa i owoce, uśmiechając się ni to do nich, ni to do stojącego obok sprzedawcy w żółtym fartuchu (plakat 9).

Specyfika zarządzania wyobraźnią społeczną na froncie domowym, której paradygmatycznym przykładem jest kampania Dig for Victory!, pozwoliła rozpatrywać kluczowe dla wojennej rzeczywistości codziennej pytanie: „przeciw komu, o co i dla kogo toczy się ta walka", (również) z perspektywy osobistego, prywatnego obowiązku względem rodziny, dzieci i najbliższej społeczności. Jej kluczowymi konstruktami były więc rozmaite wizualne reprezentacje „zwykłego obywatela (i obywatelki)” oraz „małej Anglii” (przednowoczesnej, preindustrialnej krainy). Pojęcia walki i poświęcenia zostały wysadzone poza ramy działań zbrojnych i narzucone na całą sieć codziennych folkways, które miały stać się podstawą utrzyma-

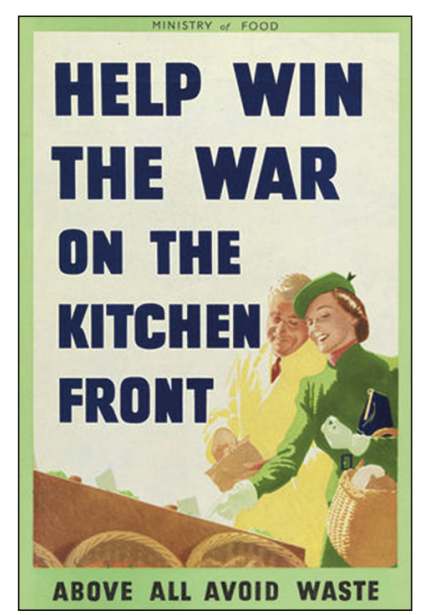

Plakat 9 nia i podtrzymywania tożsamości społeczeństwa i lokalnych więzi społecznych. Przywołane plakaty pozwalają zrekonstruować obraz frontu domowego, na którym zamiast karabinu bronią są grabie i łopata, pomysłowość i oszczędność gospodyń domowych; który pokazuje, że obowiązek ochrony kraju można realizować nie tylko poprzez posyłanie dzielnych żołnierzy do walki z wrogiem, ale że takimi bohaterami są także kobiety żywiące swoje 
rodziny z tego, co mają pod ręka, chłopcy zbierający złom (na samoloty), starszy pan z fajką kopiący grządki w przydomowym ogródku - wreszcie: samo to jedzenie (Our food is fighting!), te garnki, te warzywa, te grządki.

W pośredni, ale wyraźny sposób z plakatów kampanii Dig for Victory! wyłania się więc obraz ojczyzny, o którą warto i o którą trzeba walczyć. To wiejska, preindustrialna, spokojna, nostalgiczna kraina przeszłości, na której wspiera się sam rdzeń brytyjskości. Zauważmy, że na większości z plakatów kampanii przedstawiono okres wiosenno-letni (zbiory), przestrzeń poza miastem; przedstawiane obrazy mają niejednokrotnie pocztówkowy, chciałoby się powiedzieć, pejzażowy charakter, odmalowywane na nich postacie mają zaś najczęściej uśmiechnięte, rumiane, zdrowe twarze (na plakatach zachęcających do wstąpienia w szeregi Women's Land Army - piękne „angielskie róże" w zielono-beżowych uniformach, wsparte na widłach mrużą oczy od słońca; plakaty nawołujące do ochotniczej pracy w polu podczas zbiorów pod hasłem Lend a hand on the land przedstawiają młodych ludzi $\mathrm{w}$ roboczych ubraniach, $\mathrm{z}$ uśmiechem przerzucających siano czy zbierających jabłka).

W czasie II wojny światowej ta wiejska Anglia, a właściwie jej obraz funkcjonujący w społecznej wyobraźni, stała się symbolem brytyjskiej siły, wytrwałości i stabilności. Jak przekonuje Rebecca Lewis w The Planning, Design, and Reception of British Home Front Propaganda Posters in the Second World War ${ }^{8}$, kampanie propagandowe brytyjskiego frontu domowego $\mathrm{w}$ mniej lub bardziej świadomy i oczywisty sposób budowały perswazyjne narracje $\mathrm{z}$ użyciem dychotomicznej pary wieś-miasto. Ta pierwsza stanowiła miejsce kojarzone z prawdziwym domem, bezpieczeństwem, spokojem, dobrobytem, miasto zaś było przestrzenią strachu, niedostatku i niebezpieczeństwa. Na szerszym planie, akcentowanie znaczenia brytyjskiej „wiejskości” pozwalało zobrazować toczącą się wojnę jako zmagania "ludzkiej”, agrarnej Wielkiej Brytanii i pozbawionych serca, pogrążonych w chaosie, przemysłowych Niemiec. Mówiąc inaczej, obecność soczystej zieleni i lazurowego błękitu na propagandowych plakatach brytyjskiego frontu domowego miała nie tylko charakter ilustracyjny i nie ograniczała się jedynie do kampanii na rzecz zakładania ogródków domowych czy jedzenia świeżych warzyw i owoców, ale stanowiła niejako tło dla podtrzymywania ważnego dla formułowania kształtu tożsamości narodowej mitu „prawdziwej Anglii [deep England $]^{\prime 9}$ - zielonej krainy pełnej urokliwych dolin i słonecznych wzgórz,

8 Publikacja dostępna na: http://ww2poster.wordpress.com/phd-research/phd-thesisdesign/ (dostęp: 01 X 2012).

9 Opisuje go Angus Calder (1991). 
Dr Carrot i Potato Pete w ogrodzie zwycięstwa. Brytyjska propaganda na froncie domowym...

bukolicznego krajobrazu symbolizującego bezpieczeństwo, spokój, stabilność, tradycję łącząca przeszłość z teraźniejszością. Co znamienne i warte uwagi w tym kontekście - konotowanie brytyjskości na plakatach odbywało się właśnie głównie poprzez odniesienia do tradycji, swojskości, tego, co nasze. Dlatego też na plakatach serii zatytułowanej „To twoja Brytania, walcz o nią" (1942), Frank Newbould nie odmalowuje zbombardowanego Londynu, głodnych sierot, rozpaczających matek czy ruszających do ataku żołnierzy, ale kolorowe migawki z codziennego życia na angielskiej prowincji: wesołe miasteczko pełne bawiących się, szczęśliwych ludzi, panoramę miasteczka ze strzelistą wieżą kościoła, rozłożyste drzewo, w którego cieniu odpoczywają dzieci czy wreszcie rozciągające się po horyzont pola, którymi kroczy pasterz ze swoim psem i stadkiem śnieżnobiałych owiec (plakat 10).

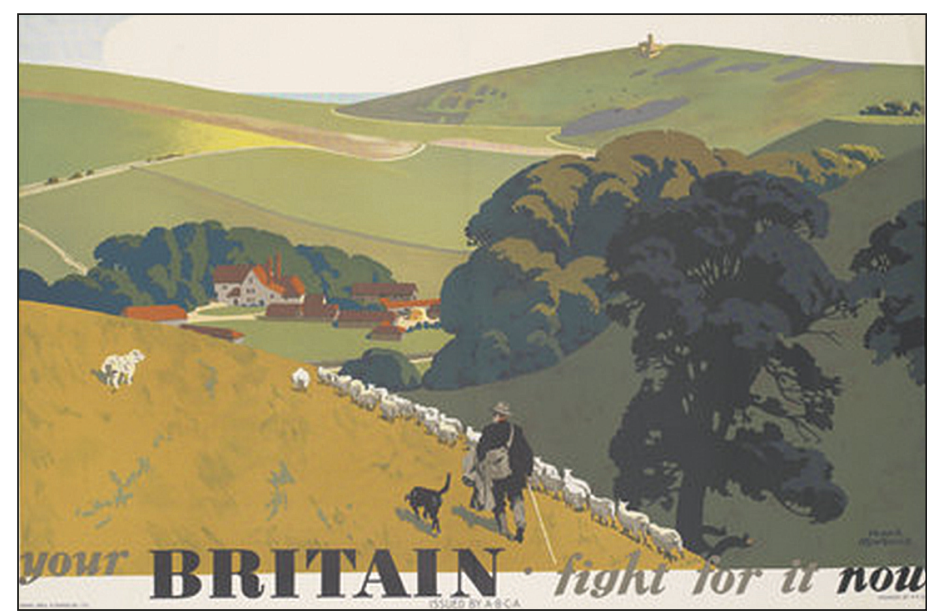

Plakat 10

\section{Bibliografia}

Calder, A., (1991), The Myth of the Blitz. London: Jonathan Cape.

Lewis, R.M., (2004), The Planning, Design, and Reception of British Home Front Propaganda Posters in the Second World War; publikacja elektroniczna: http://ww2poster.wordpress. com/phd-research/phd-thesis-design/.

Messinger, G.S., (1992), British propaganda and the state in the first world war. Manchester: Manchester University Press.

Rhodes, A., (1983), Propaganda. The Art of Persuasion in World War II. New York: Chelsea House Publishers. 


\section{Informacje na temat wykorzystanych w pracy plakatów*}

\section{Plakat 1}

Autor: nieznany, data nieznana [1939-1945]

Tytul: Food is a munition of war

Źródło: Imperial War Museum, www.iwm.org.uk, numer katalogowy IWM PST 20687

\section{Plakat 2}

Autor: nieznany, data nieznana [1939-1945]

Tytuł: I'm a protective food

Źródło: Imperial War Museum, iwm.org.uk, numer katalogowy IWM PST 20603

\section{Plakat 3}

Autor: Hank Porter, 1941

Tytuł: Doctor Carrot the Children's best friend

Źródło: Imperial War Museum, www.iwm.org.uk, numer katalogowy IWM PST 8105)

\section{Plakat 4}

Autor: nieznany, 1942

Tytuł: Dig for Victory

Źródło: Imperial War Museum, www.iwm.org.uk, numer katalogowy IWM PST 0059

Plakat 5

Autor: Mary Tunbridge, data nieznana

Tytuł: Dig for Victory

Źródło: Imperial War Museum, www. imw.org.uk, numer katalogowy IWM PST 0696)

\section{Plakat 6}

Autor: Mary Le Bon, 1944

Tytuł: Dig for plenty

Źródło: The National Archives, www.nationalarchives.gov.uk, numer katalogowy INF 3/98

\section{Plakat 7}

Autor: Abraham Games, 1942

Tytuł: Grow your own food

Źródło: Imperial War Museum, www.iwm.org.uk, numer katalogowy IWM PST 2916

\section{Plakat 8}

Autor: Hans Schelger, data nieznana

Tytul: For vitality eat greens

Źródło: Imperial War Museum, www.iwm.org.uk, numer katalogowy IWM PST 3084

Plakat 9

Autor: nieznany, 1940

Tytut: Help win the war on the kitchen front

Źródło: Imperial War Museum, www.iwm.org.uk, numer katalogowy IWM PST 20697

\section{Plakat 10}

Autor: Frank Newbould, 1942

Tytuł: Your Britain, fight for it now

Źródło: Imperial War Museum, www.iwm.org.uk, numer katalogowy IWM PST 14887

* Dane o plakatach w przypadku poszczególnych artykułów różnią się ze względu na zakres informacji, jakie udało się zgromadzić ich autorom. 